\title{
Forms of government collaboration at the local level in handling the COVID-19 disaster
}

\author{
Cici Safitri ${ }^{1 *}$, Tengku Rika Valentina ${ }^{1}$, and Ario Wicaksono ${ }^{2}$ \\ ${ }^{1}$ Departmen of Political Science, Faculty Social Science and Political Science, Andalas University, Padang, Indonesia \\ ${ }^{2}$ Institude for Governance and Policy Analysis, University of Canberra, Australia
}

\begin{abstract}
The current COVID-19 disaster requires serious handling, with the involvement of various parties. A different approach is shown by Nagari Pasie Laweh which is one of the in West Sumatra, namely by using a people-based approach which means that the low-level government Nagari collaborates with non-government local actors to handle and prevent COVID-19 with a different approach. clans (people united by tribes). The purpose of this research is to see how the efforts or forms of collaboration made by the Nagari Government with local actors deal with the COVID-19 disaster. This study uses a qualitative method with a descriptive approach and data collection techniques using literature studies from various articles/journals and related sources that help answer research questions. The results of this study show that the collaboration carried out by the Nagari government has made the handling of the COVID-19 disaster more optimal. Disaster management using a people-based method involves local non-governmental actors called the tigo tungku sajarangan (ninik mamak, alim ulama, cadiak pandai). The involvement of these actors helps the handling of men $\mathrm{j}$ a near to people's needs, this effort also facilitates communication between the government Nagari with society, so that collaboration raises public confidence towards the policy applied in Nagari.
\end{abstract}

\section{Introduction}

The pandemic has not ended, the number of cases has soared, with around more than 1 million Indonesians already exposed to the virus, which has made many countries lose their citizens. The government's efforts to recover the national economy in the second quarter are still experiencing shocks with the current spike in cases in June 2021. Following are daily case updates in Indonesia on 7 June 2021

Table 1. Daily COVID-19 cases in Indonesia until 7 June 2021

\begin{tabular}{|l|l|}
\hline Confirmed & $\mathbf{1 . 8 6 3 . 0 3 1}+6.993$ cases \\
\hline Active Case & $\mathbf{9 9 . 6 6 3}+1.208$ \\
\hline get well & $\mathbf{1 . 7 1 1 . 5 6 5}+5.594$ \\
\hline Died & $\mathbf{5 1 . 8 0 3}+191$ \\
\hline
\end{tabular}

From the table above, it can be seen that the number of cases that occurred until June 2021 continues to increase, requires special attention from the government for the sake of national security and the impact that will be caused and felt by the community. Not to mention the government's efforts to control the virus and its impact on the community are still not optimal in reducing cases until now. This makes the government have to tighten policies and collaborate with local governments so that case by case does not experience a significant increase. This unrest is experienced not only by the central government but also by local governments. The regional government must make efforts so that the region does not experience a downturn during this pandemic, including West Sumatra.

Nagari is a leading government that has the power to interact directly with the community. Nagari can also make various efforts in dealing with disasters. Collaboration between the central-regional government and all elements of society is the main key in controlling the virus. West Sumatra, with its local wisdom and unique culture, has made the handling of the COVID-19 disaster in collaboration between the Nagari government and local non-governmental actors consisting of Tigo tungku sajarangan (ninik Mamak, alim ulama, cadiak pandai). This makes the efforts of the Nagari government easier and touches the needs of the people in Nagari. To control the virus, the Nagari government has implemented policies by the direction of the central government, such as establishing a COVID-19 post in each region. However, the establishment of a post without support and collaboration with local actors will not work well. The synergy built by the Nagari government through central elements in society is also important for the smooth running of the policies carried out.

\footnotetext{
* Corresponding author: cicisaafitri@gmail.com
} 
This form of collaboration built by the Nagari Government with local actors is called a people-based approach in handling the COVID-19 disaster in Nagari in West Sumatra, one of which is Nagari Pasie Laweh who is the locus of this research. This method or approach is used in all aspects, both in the form of virus control as well as handling and preventing the impacts caused by the COVID-19 disaster. Not infrequently, many studies related to the handling of COVID-19 carried out in various regions in Indonesia are also carried out following local norms and culture so that it is easier to reach the needs of the community. This synergy can also increase the community's legitimacy to the Nagari government in handling COVID-19. The involvement of all elements of society is an important aspect of the success of the policies to be implemented.

Many previous studies serve as references for researchers who have conducted similar research including $[4,1,7,3,2]$ this category of research talks about the readiness of local governments in dealing with the COVID-19 pandemic outbreak and the efforts made. The research above can help the authors find that to see the readiness and how the local government deals with this outbreak, it has not been seen from the lowest government which also makes efforts to prevent and handle the virus, but has not been explained more fundamentally by the four studies above. The involvement of the Nagari government as the lowest government can also be seen in its efforts to help deal with the outbreak. This is what the author wants to examine in this research. Disaster management efforts carried out by the Nagari government have a relationship with the government's success in handling this disaster.

\section{Research Question}

This people-based method is an important factor to see how the Nagari government is handling this disaster, both in controlling the virus, preventing and handling COVID19 which has been regulated in the policies of the central government, but how is the form of collaboration between the Nagari government and local actors in handling this disaster? the COVID-19 disaster at the local level? The purpose of this study is to further see and analyze how the efforts or forms of collaboration made by the Nagari Government with local actors to deal with the COVID-19 disaster.

\section{Research Method}

This study uses descriptive qualitative methods to analyze how the form of collaboration carried out by the Nagari with local actors in dealing with the COVID-19 disaster. Descriptive analysis method to collect data and information on phenomena or actual problems through the process of data collection, compilation, processing, and concluding, which seeks to describe an objective empirical situation on the phenomenon or problem being studied. The data collection technique the researcher uses is a literature study, due to the limitations of the researcher to conduct direct interviews with the informants in this study.

A literature review is a critical and in-depth evaluation of previous research, also a good literature review is done by evaluating new findings from scientific articles/journals. It does not stop at the reading process alone; the researcher also summarizes making analysis and critical and in-depth synthesis of the articles/journals reviewed. Furthermore, the data is analyzed by the principles of the exploratory postpositive method, besides the researcher will obtain data from reports (articles/journals and documentation related to research) a large amount of data will be reduced by researchers by making abstractions as a core summary.

\section{Literatur Review}

Many scholars discuss the handling of the COVID-19 disaster at the domestic and national levels. Several categories of group researchers start from research on handling COVID-19 at the National level and the local level. Various forms of policies that were born from the central government must of course be in line with the policies carried out by the local government so that efforts to overcome and handle COVID-19 are optimal to break the chain of the spread of the COVID-19 virus. Like the research conducted by [1] regarding policy analysis for handling the COVID-19 outbreak: Indonesia's experience. The efforts of the Indonesian government in handling cases of the spread of the coronavirus can be understood by the efforts, steps, and policies implemented by the government so that they can see the handling strategy. Using a deliberative policy approach, this research shows that the government's response to the spread of COVID-19 is still slow because, at the beginning of the first case entering Indonesia, there was still no feeling of a crisis that endangered national security. Furthermore, the lack of coordination between stakeholders, both the central and local governments, the lack of synchronicity of the coordination has resulted in very slow virus control. When viewed from the aspect of society, they also disobeyed the government's appeal, which in the end did not synergize these three elements, causing the handling of the COVID-19 disaster to be slow at the beginning.

The research revealed [1] is an evaluation for both central and regional governments, as well as the community to carry out various policy efforts in handling this disaster. From time to time, there are many breakthroughs made by the central and regional governments such as research conducted by [10] which says that communication in disasters is an important part of handling every disaster, including the COVID-19 pandemic. His research entitled "Disaster Communications for Handling Coronavirus Diseases. 2019 (COVID-19) in Indonesia" revealed that communication is needed to build public trust to prevent public panic. This study explains the various steps and policies of the Indonesian government in dealing with COVID-19, especially in managing the flow of information and maintaining good communication to the 
public to maintain transparency and prevent mass hysteria. Communication is an important component in response and recovery, communication can also contact all elements, agencies, communities that work together to stop the spread of the virus. The availability of reliable information and communication is important in disaster management, the government must be able to ensure that the public can easily get information about the development of COVID-19. So that the availability of clear information and communication also helps all elements to act by policies and needs for handling COVID-19.

If this can be built, then all policies and collaborations between these elements can work. Research from [5] also talks about the harmonization of the authority to handle the COVID-19 pandemic between the central and local governments, seen from the health quarantine law policy. The law stipulates that COVID-19 is designated by the central government as a health emergency. The central government and local governments work together to make efforts to ensure the availability of the necessary resources in the implementation of health quarantine, namely through the establishment of a task force for handling COVID-19, providing health facilities, providing education on the dangers of COVID-19 to the entire community by mobilizing all stakeholders to participate in dealing with COVID-19. -19, provide social safety nets and deal with economic impacts. There are still problems such as the lack of coordination, communication, and synergy that was felt at the beginning of the pandemic. the government should respond quickly, which ultimately greatly affects the handling process. However, it has been seen that the government is increasingly focused and realizes that coordination is an important aspect, this can be seen from the existence of task forces and studies of the status of various regions in Indonesia.

The next category of researchers looks at the handling of COVID-19 from the domestic aspect, namely how the government at the local level can handle the COVID-19 disaster, such as research conducted by [6] talking about local leadership during the COVID-19 pandemic: Responses, Policy, and the Electoral Stage. This research was conducted in four provinces, namely DKI Jakarta, West Java, Central Java, and East Java in the face of the COVID-19 pandemic. This study uses literature review and descriptive analysis which reveals that local leaders in four provinces not only have a role in controlling the virus but also have a role in maintaining many aspects, such as health, social and economic. To deal with this dangerous threat, local leaders coordinate with central leaders, issue public policies in the regions, and encourage active community participation. In addition, the role of leaders at the local level also raises the view that the performance of leaders related to controlling the COVID19 virus at the subnational level will push the prospect of political leadership to the national political stage.

This is in line with the research conducted by [9] which talks about local leadership issues in the COVID19 pandemic. His research, entitled building cooperation and activating the role of local leadership: The Penta helix strategy for handling the impact of COVID-19. His study [9] revealed that cooperation and local leadership are the dominant characteristics of social capital practices in Indonesia. In an organic or systematic sense, it becomes a thread of synergy and integration between stakeholders. Therefore, packaging and strengthening social capital in policies with the Penta helix framework is the ultimate arrow in handling the COVID-19 pandemic. With Penta helix, the community's social capital can be used to deal with COVID-19. This makes the community more creative in building and modifying social capital for the prevention and handling of the pandemic.

Social capital is also positioned appropriately in government policies and programs, the vision, and mission of business actors, evidence-based policy formulation activities (evidence) from academic groups, being part of public campaigns that can be carried out in the media, and a new spirit in building cooperation and activating the role of local leadership for pandemic response mechanisms at all stages of the disaster management cycle.

\section{Result}

\subsection{Forms of collaboration with local governments in dealing with the COVID-19 disaster}

One of the Nagari that is the focus of this research is Nagari Pasie Laweh, Palupuh District, Lima Puluh Kota Regency, West Sumatra Province. This Nagari has innovations to carry out COVID-19 disaster management at the Nagari level (local level). The policies that have been implemented by the center to the regions are managed by the Nagari Pasie Laweh government based on local wisdom and local culture. Such as regional quarantine policies, isolation houses, handling and prevention, handwashing assistance facilities can be managed and run properly through people-based methods.

This method means that the applied policies are applied based on local values, numbers, and local cultural wisdom, by utilizing local actors and the community who can help optimize policies. Kaum is defined as a group, or tribe living in one Nagari. So, the activities of the Nagari or the Nagari Government must involve the tribes in the Nagari as an effort to synergize in carrying out the goals to be achieved together. The involvement of local nongovernment actors is an important synergy and collaboration to gain legitimacy from all elements of society. As revealed by [10] that communication is an important aspect in disaster management, communication can increase synergy and collaboration between elements of both government and society as well as other institutions that create public trust. The involvement of local non-governmental actors consists of Ninik Mamak from each clan in Nagari Pasie Laweh.

The government of Nagari Pasie Laweh uses peoplebased methods to prevent and manage the COVID-19 disaster and also makes village fund management successful during the COVID-19 pandemic so that it is in line with government policies and the needs of the Nagari people. The government of Nagari Pasie Laweh is synergizing and collaborating with 100 Ninik Mamak in 
the Nagari to jointly build the Nagari and avoid the impacts caused by the current pandemic, starting from the health, economy, and social community.

The form of synergy built by the Nagari government with this local actor(100 Ninik Mamak) can be seen through the policies of the Nagari Pasie Laweh government in line with the direction of the central government, namely as follows

1. The establishment of the COVID-19 handling post

By ministerial directives and circulars, the Nagari

Pasie Laweh government established a COVID-19 post which aims to be an initial screening location, for the public or anyone who enters Nagari must pass through the post. At this post, there are screenings such as recording and requesting a report on travel history and destinations to Nagari Pasie Laweh. The command post is provided with medical equipment, such as a body temperature checker, a place to wash hands, and a supply of masks. The guarding of this post consists of staff from the Nagari Government, Ninik Mamak, Youth, and Community (in rotation) to carry out monitoring.

2. Forming a COVID-19 education team, this education team consists of all elements in Nagari Pasie Laweh consisting of Midwives, Babinsa (Village Trustees), Bhabinkamtibmas (Bhayangkara Pembina Community Security and Order), MUI Nagari, Ninik Mamak, Youth, and Nagari staff who also brought questionnaires. to measure people's knowledge of COVID-19, as well as what are the impacts on community activities and the economy. Furthermore, this activity also asked for advice from the community for handling COVID-19 to the needs of the community.

3. Establishment of data and information center. Here we are connected with various data that has been provided by the Nagari government related to the COVID-19 case. How many people entered Nagari, Until April 18,2020 , based on the data that researchers got, 75 immigrants, entered Nagari with distribution areas of Jakarta, Riau, and Malaysia. We can find these data at the Wali Nagari office; there are also available data on recipients of $\mathrm{PKH}$ assistance, social assistance, and other assistance so that no more people receive two aids at once. In addition, such as Village Cash Direct Assistance (BLT-DD), the Nagari government also cooperates with ninik Mamak to formulate and determine at the Nagari Musrebang who is entitled to receive the assistance. This involvement is also reasonable because ninik mamak's closeness to their people, and it is felt that they know more about the family's economic situation during society are also taken into consideration by the Nagari Government.

The collaboration can be seen on the chart handling agency COVID-19 in Nagari Pasie Laweh in this Fig. 1 This form of synergy between the Government at the local level and non-government actors seems to greatly facilitate the Nagari government in preventing and overcoming COVID-19. The collaboration between the two has resulted in good collaboration so that it gains legitimacy and active participation from the community to support efforts to reduce the impact of the COVID-19 virus. When viewed from Fig 1. looks actor local (ninik Mamak) has a line parallel with the Wali Jurong to synergize to handle efforts nan close to the community. resulting collaboration and cooperation as formation posts COVID-19, team educate the COVID-19, the establishment of data centers and information, as well as the warehouse logistics.

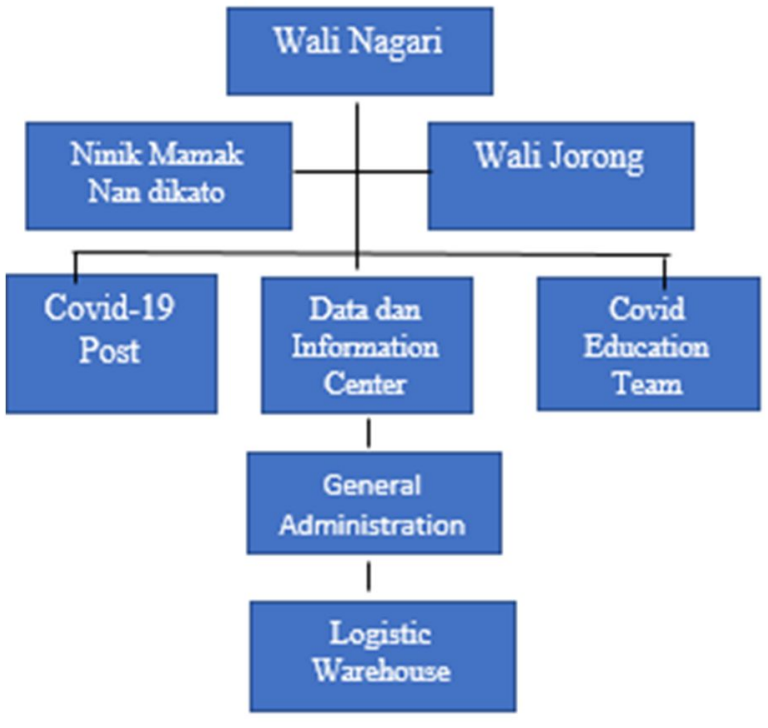

Fig. 1. Chart of institutions handling COVID-19 Nagari Pasie Laweh

Not only that, another innovation that can be utilized by Nagari Pasie Laweh in collaboration with ninik Mamak outside of central government policies or regulations is the innovation of using the Rumah gadang as an isolation house, with the agreement of the people and ninik mamak. The Nagari government has succeeded in cooperating to establish this isolation house. The isolation house used is an unoccupied house belonging to the people that can be used for people who are exposed to the virus. Furthermore, people exposed to the virus who are in isolation at home are the responsibility of their people. So, the community or ninik Mamak helps the needs of the people who are in isolation, such as providing food and vitamin intake.

In addition, to empower affected communities such as those in PHK, or not working, WFH, and people who have lost their income due to the pandemic are empowered through the management of vacant communal lands. The ninik Mamak of each clan allowed the Nagari government to be managed temporarily to be able to help the community and meet their daily basic needs. This collaboration between the Nagari government and ninik Mamak helps all elements of society to reduce the economic impact. The Nagari government provided funds to buy fish seeds, and plantation seeds to be managed in the vacant land. The results of these seeds can be distributed to the community later. The Nagari government and ninik Mamak invite and take turns empowering the community to manage the land.

This people-based approach or method was successfully applied by the Nagari Pasie Laweh 
Government to cope with the COVID-19 disaster. This synergy and collaboration between the Nagari government and local non-government actors can make disaster management more optimal. So that the role of both becomes important to achieve the needs and welfare of the people in Nagari Pasie Laweh. Collaborative cannot always be done either between the government and the government alone or with institutions/institutions. however, it is also necessary to collaborate with actors or community groups who are deemed to be able to build public trust so that there is legitimacy to carry out optimal activities or policies.

\section{Conclusion}

The government's collaboration at the local level in dealing with the COVID-19 disaster in Nagari Pasie Laweh is quite effective. The collaboration built by the Nagari government with local non-government actors, namely Ninik Mamak, has made the handling and prevention of the COVID-19 disaster run well. Utilization through aspects of local wisdom and cultural norms is also an important aspect in disaster management at the local level. This is proven by the several forms of collaboration that give birth to innovations that are closer and by the needs of the community. It is important to know that making the community feel involved is also an aspect to build public trust in the policies that will be implemented.

The support of elements of the community at the local level for the policy makes this response closer to the community. The people-based approach in Nagari Pasie Laweh can also be used as a reference for regions that have local wisdom and culture that can help the Nagari government to be stronger in carrying out the policies that are implemented. The needs and welfare of the community in Nagari become more important with various approaches that can be taken and various forms of synergy and collaboration with actors or elements of the community.

\section{References}

1. L. Agustino, Analyses of the Policy for handling the COVID-19 outbreak: the experience of Indonesia. Analyses of the COVID-19 outbreak handling policy: the experience of Indonesia. Journal of Borneo Administrator, 16 (2), 253-270 (2020)
2. RM. Amin, RF. Envelope, B Wicaksono, Handling COVID-19 from a Collaborative Governance Perspective in Pekanbaru City. 13, 1-13 (2021)

3. A. Arie, S. Dharma. The COVID-19 Infodemic in an Open Government Perspective : A Literature Review. 6 (1) (2021)

4. D. Aromatica,. Strengthening the Capacity of the Solok District Local Government in Handling COVID-19 Through Collaborative Governance. 2008, 138-141 (2020)

5. S. Khadijah, Harmonization of the authorities for handling the COVID-19 pandemic between the central and regional governments. Journal of Kertha Semaya, 8 (6), 858-866 (2020)

6. RH Imawan, I Syafii, MR Surya, P Prayoga,. Local Leadership in the Time of the COVID-19 Pandemic: Response, Policy, and the Electoral Stage. Journal of Political Research, 17 (2), 195-281 (2020)

7. DR. Hizbaron, D. Ruslanjari, D. Mardiatno. Amidst COVID-19 Pandemic: An Adaptive Disaster Governance (2021)

9. MA. Humaedi, SS Purwaningsih, LV Sunday, R. Fathy,. Building cooperation and activating the role of local leadership : Penta helix strategy for handling the impact of the COVID-19 role of local leadership : pentahelix's strategy for handling the impact of COVID-19. 23 (1), 39-58 (2021)

10. F. Noor, F. Ayuningtyas, W Prihatiningsih. International Journal of Multicultural and Multireligious Understanding Disaster Communications for Handling Coronavirus Disease 2019 (COVID-19) in Indonesia. Journal of Multicultural and Multireligious Understanding (IJMMU), 7 (4), 25-35 (2020)

11. Tribunsumbar.com, 2020. Paste Laweh Manages Village Funds and Hands I COVID-19 Base on People. In Access

(https://www.tribunsumbar.com/pasie-lawehkelola-dana-desa-dan-tangani-COVID-19berbasiskan-kaum/) On 15 May 2021

12. Binews.id, 2020. Pasi e Laweh Manages Village Funds and Handles COVID-19 Always Baiyo Batido with Ninik mamak. accessed at ( https://www.binews.id/berita/3209/pasie-lawehkelola-dana-desa-dan-tangani-COVID-19-berbasiskaum.html ) On May 152021 